\title{
Does Green Energy Complement Economic Growth for Achieving Environmental Sustainability? Evidence from Saudi Arabia
}

\author{
Montassar Kahia ${ }^{1}$, Anis Omri ${ }^{2, *}$ (1) and Bilel Jarraya ${ }^{3}$ \\ 1 Department of Economics and Finance, College of Business and Economics, Qassim University, P.O. Box 6640, \\ Buraidah 51452, Qassim, Saudi Arabia; m.kahia@qu.edu.sa \\ 2 Department of Business Administration, College of Business and Economics, Qassim University, \\ P.O. Box 6640, Buraidah 51452, Qassim, Saudi Arabia \\ 3 Department of Accounting, College of Business and Economics, Qassim University, P.O. Box 6640, \\ Buraidah 51452, Qassim, Saudi Arabia; b.jarraya@qu.edu.sa \\ * Correspondence: a.omri@qu.edu.sa; Tel.: +966-532752600
}

Citation: Kahia, M.; Omri, A.; Jarraya, B. Does Green Energy Complement Economic Growth for Achieving Environmental Sustainability?

Evidence from Saudi Arabia.

Sustainability 2021, 13, 180.

https://dx.doi.org/10.3390/su13010180

Received: 9 November 2020

Accepted: 21 December 2020

Published: 27 December 2020

Publisher's Note: MDPI stays neutral with regard to jurisdictional claims in published maps and institutional affiliations.

Copyright: () 2020 by the authors. Licensee MDPI, Basel, Switzerland. This article is an open access article distributed under the terms and conditions of the Creative Commons Attribution (CC BY) license (https: / / creativecommons.org/ licenses/by/4.0/).

\begin{abstract}
This study extends previous environmental sustainability literature by investigating the joint impact of economic growth and renewable energy on reducing $\mathrm{CO}_{2}$ emissions in Saudi Arabia over the period 1990-2016. Using the fully modified ordinary least-square (FMOLS) and dynamic ordinary least-square DOLS estimators, we find that economic growth increases $\mathrm{CO}_{2}$ emissions in all estimated models. Moreover, the validity of the environmental Kuznets curve (EKC) hypothesis is only supported for $\mathrm{CO}_{2}$ emissions from liquid fuel consumption. The invalidity of the EKC hypothesis in the most commonly used models implies that economic growth alone is not sufficient to enhance environmental quality. Renewable energy is found to have a weak influence on reducing the indicators of environmental degradation. We also find that the joint impact of renewable energy consumption and economic growth on the indicators of $\mathrm{CO}_{2}$ emissions is negative and insignificant for all the estimated models, meaning that the level of renewable energy consumption in Saudi Arabia is not sufficient to moderate the negative effect of economic growth on environmental quality. Implications for policy are also discussed.
\end{abstract}

Keywords: environmental quality; economic growth; $\mathrm{CO}_{2}$ emissions; Saudi Arabia

\section{Introduction}

The current focus on environmental issues is highly alarming and is taking place in major research and media spaces all over the world [1]. In fact, the principal danger posed to humanity is global warming caused by greenhouse gas (GHG) accumulation, mainly carbon dioxide $\left(\mathrm{CO}_{2}\right)$. One of the key reasons for this phenomenon is assumed to be rising economic growth and the consequent environmental deterioration [2]. In looking for rapid economic growth, people still hope to protect the environment efficiently and expect that the economy will expand quickly if environmental security is assured [3]. The World Bank [4] estimated that climatic change is expected to invert economic gains that have been barely realized and that developing countries will incur the most massive toll, around 75 to 80 percent of the costs of climate change damage [5]. Regarded as a severe threat in developed and developing economies, environmental concerns have become increasingly serious since the first Rio Summit was held in 1992. Since then, through the Kyoto Protocol in 1997 and its entry into force in 2005, the United Nations has been committed to reducing GHG emissions. In June 2013, 191 countries ratified and signed the Kyoto Protocol [6]. In 2015, a further effort was made in Paris (COP 21) to maintain the functioning of the system to avoid unfavorable climate change; the Paris Agreement is considered as the first international climate change agreement containing all countries' policy commitments [7]. The main aim of the Paris Agreement was to promote a transition from 
existing policy to climate neutrality by the end of the century. With regard to pollution reductions, policymakers have accepted that keeping global surface temperature increases well below $2{ }^{\circ} \mathrm{C}$ compared to pre-industrial levels should be a long-term priority, with a view to reducing the increase to $1.5^{\circ} \mathrm{C}$, in order to minimize the threats and impacts of climate changes considerably [8]. In order to meet this long-term temperature target and attain a climate-neutral world, countries must achieve worldwide emission peaks by the middle of the century. While progress to meet the objectives of the Paris Agreement on climate change still needs to be dramatically improved, it has also contributed to lowcarbon technologies and to new markets in the years following its entry into force. Regions, countries, companies and towns are setting carbon neutrality goals. Zero-carbon strategies across economic industries, accounting for $25 \%$ of emissions, are becoming sustainable. This pattern is most apparent in the power and transport sectors and has presented early movers with many potential market opportunities [9]. This consciousness is so important because the growth of $\mathrm{CO}_{2}$ emissions has been accelerated in many countries due to economic growth and the excessive use of fossil fuels. This makes it imperative to reduce GHG emissions, primarily $\mathrm{CO}_{2}$ emissions, with the aim of supporting sustainable development and mitigating climate change. The analysis of environmental degradation determinants is a fascinating topic in the economic literature. Most of the earlier research attempted to investigate the environmental Kuznets curve (EKC) linking environmental degradation indicators and per capita income ([10-15] among others). EKC theory postulates that environmental deterioration is exacerbated at the initial stages of economic growth but that, apart from certain levels of development (or per capita income), this condition changes and the environmental condition improves because of the increasing per income per capita [1]. Nevertheless, the EKC empirical assessment found that revenue was a proxy for too many other variables in a reduced model (e.g., levels of activity, economic structure, etc.), leading to a missing variable bias [16].

Moreover, recent studies in energy economics highlight the potential for a viable replacement of nonrenewable energy sources, such as coal, natural gas, or oil, in the use of renewable energy sources (solar, wind, or hydropower), as well as remarking on the vital position of such energy sources in reducing $\mathrm{CO}_{2}$ emissions in developing countries in particular, including the Kingdom of Saudi Arabia [17-22]. Actually, Saudi Arabia generates its entire energy supply through crude oil and fossil fuels, which both domestically absorb much of the country's oil supplies and become the source of greenhouse emissions. However, according to The Saudi Vision 2030 [23,24], the country can produce 20 percent of its required electricity by consuming green energy, e.g., solar and wind energy. According to the Saudi government reports, the country is aiming for a 2-million-barrel daily reduction of energy use by 2030. In 2019, the country launched 12 renewable energy projects to achieve the above objective, changing the country's overall energy system [22,25]. Recently, various government projects have been undertaken to diminish crude oil exploitation, reduce the pressure on the Saudi economy, and regulate emissions. The 2030 Saudi Vision focuses on renewable sources $[26,27]$. However, the current study aims, in light of these facts, to explore the complementarity between economic growth and renewable energy in reducing $\mathrm{CO}_{2}$ emissions in Saudi Arabia. Three theoretical elements justify the placement of this article: (i) The key reasons for the focus on Saudi Arabia, (ii) the impact of economic growth on environmental quality, and (iii) the value of using renewable energy to enhance environmental quality. These ideas are explained in greater detail below.

First, our choice of Saudi Arabia was inspired by the substantial growth in $\mathrm{CO}_{2}$ emissions and strong economic growth, accompanied by structural changes and diversification of the Saudi Arabia economy. Besides, Saudi Arabia is the second biggest emitter of $\mathrm{CO}_{2}$ pollution in the Middle East after Iran and is one of the 10 most polluting countries in the world [21,28]. On the other hand, Saudi Arabia has an immense natural solar and wind power potential that considerably contribute to environmental improvement, raising community awareness about the menace of climate change. The association between atmospheric pollution and macroeconomic variables is thus the key focal point of this 
paper, which is intended to assess the complementarity between economic growth and renewables in decreasing carbon dioxide emissions for the case of Saudi Arabia.

Second, many empirical studies have been carried out concerning the correlation between economic growth and environment $\left(\mathrm{CO}_{2}\right.$ emissions) through the validity of the EKC assumption, which Grossman and Krueger [29] initially explained. This assumption suggests that the environmental deterioration level increases as a country rises but begins to decrease as income increases surpass a shift. Generally, the environmental quality will worsen at first and then will increase with economic growth $[30,31]$. This assumption is hypothetically well tested and supported by a bulk of empirical articles and has been the focus of intensive researches in recent decades (for instance, [13-15,29,32-38]).

Third, succeeding attention is concentrated on the environmental effects of renewable energy. Different findings have been achieved by studies investigating a correlation between renewable energy use and $\mathrm{CO}_{2}$ emissions. In general, the empirical results are mixed and are based on the econometric approaches used (panel data or time series), the economic characteristics of the countries/country, and the time period of the investigation [39]. Silva et al. [40] employ the SVAR model to investigate the relation among real $\mathrm{GDP}$, renewable energy use, and $\mathrm{CO}_{2}$ emissions. Their results show that rising consuming renewables contribute to a reduction in $\mathrm{CO}_{2}$ emissions per capita. In order to explore the effects of financial development and renewable energy in the carbon dioxide $\left(\mathrm{CO}_{2}\right)$ and economic growth fields, Charfeddine and Kahia [39] employed a panel autoregressive vector model of Love and Zicchino [41] from 1980 to 2015 for 24 the Middle East and North African countries (MENA) and their findings suggest that renewable energy use and financial development have a minor effect and that $\mathrm{CO}_{2}$ emissions and economic growth can only be clarified marginally. These findings show that in the areas of economic development and environmental quality improvements, the renewable energy sectors in the MENA countries are still small in terms of contributions. Kahia et al. [42] explore the effects of renewable energy use, economic development, foreign direct investment inflows, and trade in carbon emissions, on the basis of a Multi-Domain-Analysis Context, for 12 middle East and North African States over the period 1980 to 2012. Results indicate that to improve the environmental quality and achieve sustainable development in the country, a major move towards using more renewable energy, international trade, and foreign direct investment is suggested. Mendonça et al. [43] address the effect of Gross Domestic Product (GDP), population growth, and renewable energy production on $\mathrm{CO}_{2}$ emissions in fifty of the world's biggest economies in 1990-2015. In order to achieve this, a hierarchical regression modeling was carried out, considering "country" as the most comprehensive and "year" as the most basic one. Renewable energy production has been verified by the findings as a means of reducing pollution. They found that the $1 \%$ rise in RE's electrical matrix in the countries decreases $\mathrm{CO}_{2}$ emissions on average by $0.13 \%$. Besides, Saidi and Omri [44] use both growth and environmental functions to show that renewable energy is effective in boosting economic growth and attuning carbon emissions by employing both VECM (Vector-Correction Model) and FMOLS (fully modified ordinary least-square) estimating procedures in 15 major countries consuming renewable energy. Results from the FMOLS method show that renewable energy production effectively improves economic growth and decreases emissions of carbon. In the case of 15 OECD Countries, Saidi and Omri [31] analyze the short-term and long-term impacts of renewable energy and nuclear energy use, using both the fully modified OLS (FMOLS) and vector mode correction (VECM) estimate approaches in the 1990-2018 period. Overall, the outcomes indicate that investing in renewable energy technologies improves environmental quality by reducing $\mathrm{CO}_{2}$ emissions. Regarding the case of a single country, for example, Cherni and Essaber Jouini [45] explored the connection between economic growth (GDP), renewable energy (RENEC), and $\mathrm{CO}_{2}$ emissions in Tunisia through the autoregressive distributed lag (ARDL) technique and the test technique of Granger causality over the period from 1990 to 2015. The findings demonstrate, in the long run, that $\mathrm{CO}_{2}$ emissions, RENEC, and GDP are steady. The causality tests in Granger however reveal a bidirectional correlation between 
$\mathrm{CO}_{2}$ emissions and GDP, and between GDP and RENEC, but no correlation between the emissions of $\mathrm{CO}_{2}$ and RENEC. Dong et al. [46] explored, within the context of the environmental curve Kuznets (EKC), the dynamic, cause, and effects associated with per capita gross domestic product (GDP), carbon-dioxide emission $\left(\mathrm{CO}_{2}\right)$, renewable energy use, nuclear energy use, and fossil-energy use for China over the 1993-2016 period through performing a variety of econometric techniques for structural breaks. Their empirical findings show that nuclear and renewable energy have an important role to play in the short term in reducing $\mathrm{CO}_{2}$ emissions while the consumption of fossil fuels is currently the primary factor in upholding $\mathrm{CO}_{2}$ emissions. In view of the contradictory evidence found in the literature between 1990 and 2014, Emir and Bekun [47] examined empirically the relation between renewable energy use, economic growth, carbon emissions, and energy intensity for Romania. In this regard, the authors performed an ARDL (autoregressive distribution lag) specification, while the causality direction has been reached by the model of Toda-Yamamoto. Their empirical results indicate that all investigated series are cointegrated and the presence of a uniform causality varies from the renewable energy use to economic growth that confirms the energy-led growth assumption.

By integrating the above three lines of research, the current study aims to examine the impact of economic growth and green energy on $\mathrm{CO}_{2}$ emissions by answering the following research question: Does renewable energy moderate the negative influence of economic growth on $\mathrm{CO}_{2}$ emissions in Saudi Arabia? To answer this interrogation, our inquiry offers the following novelties to the existing energy economics literature. First, previous studies on this topic have only focused on the validity of the EKC hypothesis (e.g., [48-52]), on the causality between renewable energy consumption and economic growth (e.g., [53-57]), or on renewable energy consumption and environmental quality (e.g., [58-62]). To the best of our knowledge, none of them has interested in demonstrating the complementary relationship between renewable energy and economic growth in reducing $\mathrm{CO}_{2}$ emissions, particularly in Saudi Arabia. Second, as mentioned above, several reasons allow us focusing on Saudi Arabia, including (i) it has the second-biggest emitter of $\mathrm{CO}_{2}$ pollution in the Middle East after Iran and is one of the 10 most polluting countries in the world; (ii) it has an immense natural solar and wind power potential that considerably contribute to environmental improvement, raising community awareness about the menace of climate change. Third, four different indicators of $\mathrm{CO}_{2}$ emissions are included in the analysis, namely $\mathrm{CO}_{2}$ emissions per capita, $\mathrm{CO}_{2}$ intensity, $\mathrm{CO}_{2}$ emissions from electricity and heat production, and $\mathrm{CO}_{2}$ emissions from the use of liquid fuel consumption.

After the introduction, Section 2 outlines the econometric methodology, while Section 3 presents and describes the used data. Section 4 exposes the main empirical findings. Section 5 concludes.

\section{Methodology}

Model Specifications

To study the complementarity between renewable energy and economic growth in reducing $\mathrm{CO}_{2}$ emissions in the case of Saudi Arabia, energy consumption, financial development, trade, and FDI are included as other determinants of $\mathrm{CO}_{2}$ emissions $[21,31,43,58,60,63]$.

The review of literature allows us to formulate the following empirical model:

$$
\ln C_{t}=\alpha_{0}+\alpha_{1} \ln Y_{t}+\alpha_{2} \ln Y^{2}{ }_{t}+\alpha_{3} \ln R E_{t}+\alpha_{4} \ln R E_{t} * \ln Y_{t}+\alpha_{5} \ln E C_{t}+\alpha_{6} \ln F D_{t}+\alpha_{7} \ln T_{t}+\alpha_{8} \ln F_{t}+\varepsilon_{t}
$$

where $t$ is the time period $(T=1, \ldots, N=27), C$ is the indicators of $\mathrm{CO}_{2}$ emissions, $Y$ is per capita GDP, $Y^{2}$ is the squared GDP, $R E$ is renewable energy consumption, $R E^{*} Y$ is the interplay between per capita GDP and renewable energy consumption, $E C$ is per capita energy consumption, $F D$ is financial development, $T$ is trade openness, $F$ is FDI, and $\varepsilon$ is the error term. The significance and signs of $\alpha_{1}, \alpha_{3}$, and $\alpha_{4}$ are of interest. We expect that the sign of per capita GDP is positive, whereas the sign of renewable energy is negative. Regarding the interactive term, we expect that its sign is negative, i.e., renewable energy complement per capita GDP to reduce $\mathrm{CO}_{2}$ emissions. Before estimating Equation (1), 
we first check the stationary properties of our series. Then, we analyze the long-run equilibrium associations among the considered series by means of the Johansen cointegration test. In the last step, we pass to estimate the long-term associations by using FMOLS and DOLS estimators.

\section{Data and Descriptive Statistics}

To estimate our empirical model, we used annual time series data for the Kingdom of Saudi Arabia for the 1990-2016 period. The data are sourced from the World Development Indicators (WDI) and the International Monetary Fund (IMF). The selected variables are the four indicators of $\mathrm{CO}_{2}$ emissions, per capita GDP, renewable energy consumption, financial development index, FDI net inflows, trade openness, and energy use.

The definition and source of these variables are reported in Table 1, whereas Table 2 exposes the summary statistics and correlations. Over the sample period, Table 2 shows that GDP per capita ranges from 16,696.41 US\$ to 21,399 US\$; the range for per capita $\mathrm{CO}_{2}$ emissions is from 10.497 to 20.402 metric tons per capita; the range for $\mathrm{CO}_{2}$ intensity is 2.259 to $3.966 \mathrm{~kg}$ of oil equivalent energy use; $\mathrm{CO}_{2}$ emissions from electricity and heat production ranges from $46.981 \%$ to $50.487 \%$ of total fuel combustion; $\mathrm{CO}_{2}$ emissions from the use of liquid fuel consumption ranges from $88,466.375$ to $413,230.563(\mathrm{kt})$, and renewable energy consumption ranges from $0.005 \%$ to $0.037 \%$ of total final energy consumption. This table further displays that GDP per capita has the uppermost association with $\mathrm{CO}_{2}$ emissions per capita, while the lowest is for the $\mathrm{CO}_{2}$ intensity variable. Regarding the $\mathrm{CO}_{2}$ emissions indicators, $\mathrm{CO}_{2}$ emissions from liquid fuel consumption have the highest correlation with renewable energy. Besides, this later is positively correlated with GDP and negatively with three out of four indicators of $\mathrm{CO}_{2}$ emissions, meaning that an increase in renewable energy consumption leads to promote economic growth without deteriorating the environment.

Table 1. Description and source of the used data.

\begin{tabular}{ccc}
\hline Variables & Description & Source \\
\hline $\mathrm{CO}_{2}$ emissions per capita $\left(\mathrm{C}_{\mathrm{pc}}\right)$ & $\mathrm{CO}_{2}$ emissions (metric tons per capita) & WDI \\
\hline $\mathrm{CO}_{2}$ intensity $\left(\mathrm{C}_{\mathrm{int}}\right)$ & $\begin{array}{c}\mathrm{CO}_{2} \text { intensity in kg of oil equivalent } \\
\text { energy use }\end{array}$ & WDI \\
\hline $\begin{array}{c}\mathrm{CO}_{2} \text { emissions from electricity } \\
\text { and heat production }\left(\mathrm{C}_{\text {elhp }}\right)\end{array}$ & $\begin{array}{c}\mathrm{CO}_{2} \text { emissions from electricity and heat } \\
\text { production, total (\% of total fuel } \\
\text { combustion) }\end{array}$ & WDI \\
\hline $\begin{array}{c}\mathrm{CO}_{2} \text { emissions from the use of } \\
\text { liquid fuel consumption }\left(\mathrm{C}_{\text {lif }}\right)\end{array}$ & $\begin{array}{c}\mathrm{CO}_{2} \text { emissions from liquid fuel } \\
\text { consumption (kt) }\end{array}$ & WDI \\
\hline GDP per capita $(\mathrm{Y})$ & $\begin{array}{c}\text { GDP per capita (constant 2010 US\$) } \\
\text { Renewable energy consumption } \\
\text { (\% of total final energy consumption) }\end{array}$ & WDI \\
\hline Financial Development (FD) & Financial Development Index & IMF \\
\hline Trade Openness & $\begin{array}{c}\text { Foreign direct investment, net inflows } \\
\text { (\% of GDP) }\end{array}$ & WDI \\
\hline Energy Consumption & $\begin{array}{c}\text { Trade is the sum of exports and imports } \\
\text { of goods and services measured as a } \\
\text { share of gross domestic product. }\end{array}$ & WDI \\
\hline $\begin{array}{c}\text { Energy use (kg of oil equivalent) per } \\
\text { \$1000 GDP (constant 2011 PPP) }\end{array}$ & WDI \\
\hline
\end{tabular}

Note: WDI indicates the World Development Indicators and IMF indicates the International Monetary Fund. 
Table 2. Summary statistics and correlations (1990-2016).

\begin{tabular}{|c|c|c|c|c|c|c|c|c|c|c|}
\hline 1 & $\mathrm{C}_{\mathrm{pc}}$ & $C_{\text {int }}$ & $\mathrm{C}_{\text {elhp }}$ & $\mathrm{C}_{\text {lif }}$ & $\mathbf{Y}$ & RE & FD & $\mathbf{F}$ & $\mathbf{T}$ & EC \\
\hline Mean & 15.843 & 3.010 & 48.710 & $233,238.362$ & $19,332.68$ & 0.012 & 0.377 & 1.785 & 74.001 & 115.441 \\
\hline Standard deviation & 2.740 & 0.434 & 1.689 & $91,793.438$ & 1207.243 & 0.009 & 0.128 & 2.622 & 11.111 & 16.803 \\
\hline Min & 10.497 & 2.259 & 46.981 & $88,466.375$ & $16,696.41$ & 0.005 & 0.188 & -1.307 & 56.088 & 83.677 \\
\hline Max & 20.402 & 3.966 & 50.487 & $413,230.563$ & $21,399.10$ & 0.037 & 0.559 & 8.496 & 96.102 & 148.902 \\
\hline $\mathrm{C}_{\mathrm{pc}}$ & 1 & & & & & & & & & \\
\hline $\mathrm{C}_{\text {int }}$ & 0.342 & 1 & & & & & & & & \\
\hline $\mathrm{C}_{\text {elph }}$ & -0.296 & -0.238 & 1 & & & & & & & \\
\hline $\mathrm{C}_{\text {lif }}$ & 0.609 & -0.165 & -0.169 & 1 & & & & & & \\
\hline $\mathrm{Y}$ & 0.695 & 0.166 & 0.324 & 0.506 & 1 & & & & & \\
\hline $\mathrm{RE}$ & -0.308 & 0.587 & -0.377 & -0.591 & 0.154 & 1 & & & & \\
\hline FD & 0.684 & -0.308 & -0.033 & 0.724 & 0.519 & 0.694 & 1 & & & \\
\hline $\mathrm{F}$ & 0.279 & -0.227 & 0.301 & 0.438 & 0.159 & 0.319 & 0.541 & 1 & & \\
\hline $\mathrm{T}$ & 0.560 & 0.010 & 0.397 & 0.694 & 0.397 & 0.270 & 0.630 & 0.703 & 1 & \\
\hline $\mathrm{EC}$ & 0.658 & 0.477 & 0.072 & 0.778 & 0.398 & 0.445 & 0.490 & 0.501 & 0.531 & 1 \\
\hline
\end{tabular}

\section{Results and Discussion}

We initiate the empirical part by checking the stationary of the used variables using a series of unit root tests, namely ADF, PP, and KPSS tests. The results of these tests at levels and first difference are reported in Table 3. It is clear from this table that all the variables we consider are integrated at one order $(\mathrm{I}(1))$, which means a possibility of cointegration relationships among variables. So we can use Johansen's cointegration test to check the long-run equilibrium relationships among variables in the four estimated models. The results of this test are reported in Table 4, which shows the rejection of the hypothesis of no cointegration for the four models. Thus, the studied variables are cointegrated, allowing us to estimate the long-run relationships in the next step.

Table 3. Results of unit root tests.

\begin{tabular}{ccccccc}
\hline \multirow{2}{*}{ Variables } & \multicolumn{2}{c}{ ADF } & \multicolumn{2}{c}{ PP } & \multicolumn{2}{c}{ KPSS } \\
\cline { 2 - 7 } & Level & $\begin{array}{c}\text { 1st } \\
\text { Difference }\end{array}$ & Level & $\begin{array}{c}\text { 1st } \\
\text { Difference }\end{array}$ & Level & $\begin{array}{c}\text { 1st } \\
\text { Difference }\end{array}$ \\
\hline $\mathrm{C}_{\mathrm{pc}}$ & -2.281 & $-4.370^{* * *}$ & -2.417 & $-6.001^{* * *}$ & 0.849 & $0.136^{* * *}$ \\
\hline $\mathrm{C}_{\mathrm{int}}$ & $-6.772^{* * *}$ & $-4.996^{* * *}$ & -2.098 & $-5.251^{* * *}$ & 0.662 & $0.098^{* * *}$ \\
\hline $\mathrm{C}_{\mathrm{elph}}$ & $-3.079^{* *}$ & $-8.195^{* * *}$ & $-3.047^{* *}$ & $-8.180^{* * *}$ & $0.172^{* * *}$ & $0.146^{* * *}$ \\
\hline $\mathrm{C}_{\text {lif }}$ & -2.485 & $-5.709^{* * *}$ & -2.479 & $-5.709^{* * *}$ & 0.257 & $0.212^{* * *}$ \\
\hline $\mathrm{Y}$ & -1.449 & $-5.596^{* * *}$ & -1.449 & $-5.593^{* * *}$ & 0.857 & $0.099^{* * *}$ \\
\hline $\mathrm{Y}^{2}$ & -1.783 & $-7.039^{* * *}$ & -1.783 & $-7.035^{* * *}$ & 0.618 & $0.087^{* * *}$ \\
\hline $\mathrm{RE}$ & $-5.367^{* * *}$ & $-4.367^{* * *}$ & $-3.894^{* * *}$ & $-5.087^{* * *}$ & $0.185^{* * *}$ & $0.196^{* * *}$ \\
\hline $\mathrm{FD}$ & -1.020 & $-6.636^{* * *}$ & -1.020 & $-6.634^{* * *}$ & $0.941^{* * *}$ & $0.113^{* * *}$ \\
\hline $\mathrm{F}$ & $-2.993^{* *}$ & $-7.891^{* * *}$ & $-3.029^{* *}$ & $-8.176^{* * *}$ & 0.333 & $0.087^{* * *}$ \\
\hline $\mathrm{T}$ & -1.182 & $-3.362^{* *}$ & -1.182 & $-3.304^{* *}$ & $0.415^{* * *}$ & $0.104^{* * *}$ \\
\hline $\mathrm{EC}$ & $-2.287^{* * *}$ & $-6.284^{* * *}$ & -2.326 & $-6.265^{* * *}$ & $0.822^{* * *}$ & $0.080^{* * *}$ \\
\hline Note: & and & & &
\end{tabular}


Table 4. Results of Johansen's cointegration test.

\begin{tabular}{|c|c|c|c|c|c|c|c|c|}
\hline \multirow{2}{*}{$\begin{array}{c}\text { Models } \\
\text { Number of } \\
\text { Cointegrating } \\
\text { Equations }\end{array}$} & \multicolumn{2}{|c|}{ Model 1: $C_{p c}$} & \multicolumn{2}{|c|}{ Model 2: $\mathrm{C}_{\text {int }}$} & \multicolumn{2}{|c|}{ Model 3: $\mathrm{C}_{\text {elph }}$} & \multicolumn{2}{|c|}{ Model 4: $C_{\text {lif }}$} \\
\hline & Trace Test & $\begin{array}{c}\text { Max-Eigen } \\
\text { Statistic }\end{array}$ & Trace Test & $\begin{array}{c}\text { Max-Eigen } \\
\text { Statistic }\end{array}$ & Trace Test & $\begin{array}{c}\text { Max-Eigen } \\
\text { Statistic }\end{array}$ & Trace Test & $\begin{array}{c}\text { Max-Eigen } \\
\text { Statistic }\end{array}$ \\
\hline None & $261.904^{* * *}$ & $90.844^{* * *}$ & $261.815^{* * *}$ & $93.497^{* * *}$ & $252.440^{* * *}$ & $96.011^{* * *}$ & $290.746^{* * *}$ & $103.476^{* * *}$ \\
\hline At most 1 & $171.059^{* * *}$ & $64.129 * * *$ & $168.317^{* * *}$ & $63.261^{* * *}$ & $156.429^{* * *}$ & $55.471^{* * *}$ & $187.270^{* * *}$ & $71.236^{* * *}$ \\
\hline At most 2 & $106.930 * * *$ & $54.863^{* * *}$ & $104.696^{* * *}$ & $52.041^{* * *}$ & $100.957^{* * *}$ & $44.063^{* * *}$ & $116.033^{* * *}$ & $53.694^{* * *}$ \\
\hline At most 3 & $52.066^{* * *}$ & 23.914 & $52.654 * * *$ & $25.597^{* * *}$ & $56.893^{* * *}$ & $30.484 * *$ & $62.338 * *$ & $31.336^{* *}$ \\
\hline At most 4 & 28.152 & 16.478 & 27.057 & 15.873 & 26.408 & 20.492 & 31.001 & 18.093 \\
\hline At most 5 & 11.674 & 6.587 & 11.184 & 9.364 & 17.378 & 17.374 & 23.471 & 15.335 \\
\hline At most 6 & 5.086 & 4.086 & 8.270 & 7.056 & 9.034 & 8.499 & 12.908 & 9.227 \\
\hline At most 7 & $3.382 * *$ & $3.382 * *$ & $4.127^{* *}$ & $4.127^{* *}$ & 0.534 & 0.534 & 3.680 & 3.680 \\
\hline
\end{tabular}

Table 5 reports the results of the long-run estimates (FMOLS and DOLS). The following are the main obtaining results. First, we can see that per capita GDP has a positive impact on the four indicators of $\mathrm{CO}_{2}$ emissions, ranging from 0.244 to 0.679 percent for the FMOLS estimator and from 0.192 to 0.448 percent for the DOLS estimator. This confirms the findings of Bouznit and Pablo-Romero [51], who find a positive contribution of economic growth to environmental degradation in the case of Algeria using the ARDL bounds testing approach and Omri et al. [21] in the case of Saudi Arabia using Johansen cointegration test and FMOLS and DOLS estimators. Moreover, the sign of the squared GDP is negative and statistically significant only in the model pertaining to $\mathrm{CO}_{2}$ emissions from liquid fuel, meaning a reduction of $\mathrm{CO}_{2}$ emissions from liquid fuel when per capita GDP reaches the optimal level. The positive and negative signs of per capita GDP and the squared of per capita GDP support the validity of the EKC hypothesis, i.e., an increase in per capita GDP increases initially the $\mathrm{CO}_{2}$ emissions from liquid fuel consumption but then reduces them after reaching a certain level, that is, an inverted U-shaped linkage between per capita GDP and $\mathrm{CO}_{2}$ emissions from liquid fuel consumption. It is clear that the EKC hypothesis is not proved for most of the estimated models, which means that economic growth alone is not sufficient to improve environmental quality. This result is in with the findings of Akbostanci et al. [64] and Ozturk and Acaravci [48] for Turkey.

Second, with the exception of model 4 pertaining to $\mathrm{CO}_{2}$ emissions from liquid fuel consumption, the results of both estimators show that renewable energy consumption weakly contributes to the reduction of $\mathrm{CO}_{2}$ emissions, ranging from -0.072 to -0.086 percent for the FMOLS estimator and from -0.055 to -0.097 percent for the DOLS estimators. This result is in line with the findings of Saidi and Omri [44], who show that renewable energy consumption lessens carbon dioxide emissions for 15 major renewable energy-consuming economies. It also confirms the findings of Bélaïd and Youssef [60], who investigate the interconnections among economic growth, environmental degradation, and renewable and non-renewable energy consumption and economic growth in Algeria. Their findings reveal that non-renewable energy and per capita GDP have opposing impacts on environmental degradation, particularly carbon dioxide emissions. They also find more consumption of renewable energy contributes to reducing environmental degradation. However, it contradicts the findings of Apergis et al. [58] who show that the consumption of renewable energies does not have any contribution to reduce $\mathrm{CO}_{2}$ emissions. 
Table 5. Results of long-run estimates.

\begin{tabular}{|c|c|c|c|c|c|c|c|c|}
\hline \multirow{3}{*}{$\begin{array}{l}\text { Independent } \\
\text { Variables }\end{array}$} & \multicolumn{8}{|c|}{ Dependent Variables: $\mathrm{CO}_{2}$ Emissions } \\
\hline & \multicolumn{2}{|c|}{ Model $1\left(C_{p c}\right)$} & \multicolumn{2}{|c|}{ Model $2\left(C_{\text {int }}\right)$} & \multicolumn{2}{|c|}{ Model $3\left(\mathrm{C}_{\text {elhp }}\right)$} & \multicolumn{2}{|c|}{ Model $4\left(\mathrm{C}_{\text {lif }}\right)$} \\
\hline & Coef. & Prob. & Coef. & Prob. & Coef. & Prob. & Coef. & Prob. \\
\hline \multicolumn{9}{|c|}{ FMOLS estimates } \\
\hline $\mathrm{Y}$ & $0.327^{* * *}$ & $(0.002)$ & $0.591^{* * *}$ & $(0.000)$ & $0.244^{* *}$ & $(0.013)$ & $0.679^{* * *}$ & $(0.000)$ \\
\hline $\mathrm{Y}^{2}$ & -0.086 & $(0.103)$ & 0.029 & $(0.226)$ & -0.102 & $(0.110)$ & $-0.097^{* *}$ & $(0.019)$ \\
\hline RE & $-0.077^{* *}$ & $(0.036)$ & $-0.086^{*}$ & $(0.072)$ & $-0.072 * * *$ & $(0.003)$ & 0.041 & $(0.123)$ \\
\hline$Y^{*} \mathrm{RE}$ & -0.104 & $(0.109)$ & -0.084 & $(0.116)$ & -0.106 & $(0.114)$ & -0.040 & $(0.223)$ \\
\hline FD & $0.116^{*}$ & $(0.060)$ & 0.104 & $(0.123)$ & $0.194^{* *}$ & $(0.028)$ & $0.218^{* * *}$ & $(0.000)$ \\
\hline $\mathrm{F}$ & $0.184^{* *}$ & $(0.021)$ & $0.236^{*}$ & $(0.073)$ & 0.069 & $(0.167)$ & $0.199 * *$ & $(0.012)$ \\
\hline $\mathrm{T}$ & $0.267^{* * *}$ & $(0.000)$ & $0.317^{* * *}$ & $(0.000)$ & $0.192^{* *}$ & $(0.026)$ & $0.329^{* *}$ & $(0.000)$ \\
\hline EC & $0.493^{* * *}$ & $(0.000)$ & $0.417^{* * *}$ & $(0.000)$ & $0.384^{* * *}$ & $(0.000)$ & $0.586^{* * *}$ & $(0.000)$ \\
\hline Constant & $-19.268^{* * *}$ & $(0.000)$ & $7.279^{* *}$ & $(0.031)$ & -1.389 & $(0.176)$ & $-11.029 * * *$ & $(0.000)$ \\
\hline \multicolumn{9}{|c|}{ DOLS estimates } \\
\hline $\mathrm{Y}$ & $0.205^{* *}$ & $(0.044)$ & $0.361^{* * *}$ & $(0.000)$ & $0.192^{* * *}$ & $(0.006)$ & $0.448^{* * *}$ & $(0.000)$ \\
\hline $\mathrm{Y}^{2}$ & -0.046 & $(0.134)$ & 0.070 & $(0.115)$ & -0.092 & $(0.100)$ & $-0.102^{* * *}$ & $(0.000)$ \\
\hline RE & $-0.055^{* * *}$ & $(0.000)$ & $-0.069 * *$ & $(0.020)$ & $-0.097^{* * *}$ & $(0.000)$ & 0.073 & $(0.116)$ \\
\hline$Y^{*} \mathrm{RE}$ & -0.034 & $(0.321)$ & -0.051 & $(0.292)$ & -0.009 & $(0.518)$ & -0.019 & $(0.440)$ \\
\hline FD & $0.207^{* *}$ & $(0.027)$ & $0.138 *$ & $(0.055)$ & $0.281^{* * *}$ & $(0.000)$ & $0.220 * * *$ & $(0.000)$ \\
\hline $\mathrm{F}$ & $0.193^{* * *}$ & $(0.000)$ & 0.151 * & $(0.077)$ & 0.090 & $(0.107)$ & $0.179 * *$ & $(0.040)$ \\
\hline $\mathrm{T}$ & $0.301^{* * *}$ & $(0.000)$ & $0.240^{* * *}$ & $(0.000)$ & $0.202^{* * *}$ & $(0.002)$ & 0.170 * & $(0.052)$ \\
\hline EC & $0.602^{* * *}$ & $(0.000)$ & $0.324^{* * *}$ & $(0.000)$ & $0.402^{* * *}$ & $(0.000)$ & $0.610^{* * *}$ & $(0.000)$ \\
\hline Constant & -24.366 & $(0.000)$ & $-9.006^{* *}$ & $(0.013)$ & $-10.589 * * *$ & $(0.000)$ & $7.829 *$ & $(0.065)$ \\
\hline
\end{tabular}

Note: Values in parentheses are the $p$-values; ${ }^{* * *}, * *$ and $*$ indicate significance at $1 \%, 5 \%$, and $10 \%$ levels, respectively.

Third, we concentrate on the important gap in the existing literature, i.e., demonstrating the ability of renewable energy to moderate the negative effect of economic growth on different indicators of $\mathrm{CO}_{2}$ emissions. The results of both estimators show that the impact of the interaction effect of renewable energy and economic growth on $\mathrm{CO}_{2}$ emissions is negative and insignificant for all the estimated models, meaning that the level of renewable energy consumption in Saudi Arabia is not sufficient to moderate the negative impact of economic growth on environmental degradation. This contradicts the results of Saidi and Omri [31], who find that the use of renewable energy promotes economic growth and improves environmental quality. The weak influence of the consumption of renewable energies on reducing $\mathrm{CO}_{2}$ emissions and its incapacity to moderate the negative consequences of economic growth on increasing $\mathrm{CO}_{2}$ emissions in Saudi Arabia are due to its minimum use in the country and more attention should be given to its use. Moreover, the economic growth in Saudi Arabia is largely based on oil production and it is ranked among the highest emitters of $\mathrm{CO}_{2}$ in the world. Clearly, an energy transition is vital to Saudi Arabia as the country is endowed with abundant renewable energy sources. Accordingly, policymakers in Saudi Arabia should include general measures and actions that encourage investment in renewable energy, which, in turn, increases economic growth without damaging environmental quality.

Finally, regarding the control variables, both estimators show that financial development increases environmental degradation in most of the estimated models, ranging from 0.116 to 0.218 percent for the FMOLS estimator and from 0.138 to 0.281 percent for the DOLS estimator. This confirms the results of Omri et al. [21], who study the determinants of 
environmental sustainability. Their findings show that environmental degradation in Saudi Arabia is very sensitive to the development level of the financial sector, i.e., there exists a nonlinear link between $\mathrm{CO}_{2}$ emissions and financial development. Moreover, the globalization variables, i.e., FDI and trade openness, have a positive impact on $\mathrm{CO}_{2}$ emissions in most of the estimated models. These results are in line with the findings of Kalayci and Hayaloglu [65] who examine the environmental impacts of globalization for the case of NAFTA countries. Their findings show that there is a positive relationship between trade, economic globalization, and $\mathrm{CO}_{2}$ emissions. However, our results contradict the findings of Salahuddin et al. [66], who find no causality is observed between $\mathrm{CO}_{2}$ emissions and globalization in South Africa. Energy consumption is also found to have a positive impact on $\mathrm{CO}_{2}$ emissions for both estimators, ranging from 0.384 to 0.586 percent for the FMOLS estimator and from 0.324 to 0.610 percent from the DOLS estimator. This confirms the findings of Bélaïda and Youssef [60] for Algeria.

\section{Conclusions and Policy Implications}

The role of green energy in boosting the economy and mitigating environmental degradation in Saudi Arabia is examined using annual data for the period 1990-2016. To validate this objective, we used Johansen's cointegration test and the FMOLS and DOLS long-run estimators.

The following are the main findings obtained from the long-run estimates: (i) Economic growth contributes to environmental damage in all estimated models; (ii) the validity of the EKC hypothesis is only supported for the $\mathrm{CO}_{2}$ emissions from the liquid fuel consumption. The invalidity of the EKC hypothesis in the most estimated models means that economic growth alone is not sufficient to improve environmental quality; (iii) renewable energy has a weak influence on reducing $\mathrm{CO}_{2}$ emissions; (iv) the joint impact of renewable energy consumption and economic growth on $\mathrm{CO}_{2}$ emissions is negative and insignificant for all the estimated models, meaning that the level of renewable energy consumption in Saudi Arabia is not sufficient to moderate the negative impact of economic growth on environmental degradation.

These findings lead to the following policy implications. First, the government must set an initial goal to generate gigawatts of renewable energy to improve the competitiveness of the renewable energy sector. In fact, gradual subsidy deletion and reorientation of support for renewable energy manufacturing are important to raise the renewable energy share of the overall energy mix. However, it is important to closely analyze the consequence of subsidies elimination in order to avoid affecting the lower income sector of the population. Second, the government needs to locate a substantial part of the Saudi economy's value chain for renewable energy, including manufacturing, research, and development, among other stages. Besides, the legislative and regulatory structure allowing the private sector to purchase and invest in the renewable energy sector needs to be reviewed. In fact, the literature on green energy sources indicates that three main regulatory frameworks to facilitate the production of renewable energy have been adopted internationally. According to Abdmouleh et al. [67], the Feed-In Tariff Scheme (FIT) is used in most countries worldwide (around 71 countries and 28 provinces or states). In addition, 22 economies and 54 provinces or states are implementing the Renewable Portfolio Standard (RPS) and the third regulatory policy is Net Metering, enforced by 37 countries and 51 provinces or states. It is important to research in detail which kind of legislative strategy would be more effective for Saudi Arabia as it depends on the economic structure of the country and its features. Besides, Saudi Arabia can benefit from a range of incentives like the Clean Development Mechanism (CDM). The CDM provides tremendous potential advantages for Saudi Arabia, primarily due to the renewable energy production potential of this area. For example, Saudi Arabia should take advantage of CDM by introducing many green energy programs, since it allows revenue to be generated from decreasing GHG emissions. For example, a reduction of one ton of $\mathrm{CO}_{2}$ emissions is equal to one credit and can be exchanged on foreign markets $[19,68]$. Moreover, it is also important to foster public-private 
collaborations to locate the industry and produce the required skills. Finally, a gradual market liberalization of fuels is essential to ensure renewable energy competitiveness.

Author Contributions: Conceptualization, A.O.; methodology, A.O.; software, A.O.; validation, M.K., A.O., and B.J.; formal analysis, M.K.; investigation, B.J.; resources, M.K.; data curation, B.J.; writing—original draft preparation, A.O.; writing—review and editing, M.K. and A.O.; visualization, M.K.; supervision, A.O.; project administration, M.K.; funding acquisition, M.K., A.O., and B.J. All authors have read and agreed to the published version of the manuscript.

Funding: This research was funded by Qassim University in Saudi Arabia, grant number 5522-cbe2019-2-2-I. The APC was funded by Qassim University.

Data Availability Statement: Data available upon request.

Acknowledgments: The authors gratefully acknowledge Qassim University, represented by the Deanship of Scientific Research, on the financial support for this research under the number (5522cbe-2019-2-2-I) during the academic year 1441AH/2019 AD.

Conflicts of Interest: The authors declare no conflict of interest.

\section{References}

1. Alkhathlan, K.; Javid, M. Energy consumption, carbon emissions and economic growth in Saudi Arabia: An aggregate and disaggregate analysis. Energy Policy 2013, 62, 1525-1532. [CrossRef]

2. Alagidede, P.; Adu, G.; Frimpong, P.B. The effect of climate change on economic growth: Evidence from Sub-Saharan Africa. Environ. Econ. Policy Stud. 2016, 18, 417-436. [CrossRef]

3. Rao, C.; Yan, B. Study on the interactive influence between economic growth and environmental pollution. Environ. Sci. Pollut. Res. 2020, 27, 39442-39465. [CrossRef] [PubMed]

4. World Bank. Report on the Development in the World 2010: Development and Climate Change; World Bank: Washington, DC, USA, 2010.

5. Hope, C. How deep should the deep cuts Be? Optimal $\mathrm{CO}_{2}$ emissions over time under uncertainty. Clim. Policy 2009, 9, 3-8. [CrossRef]

6. Alshehry, A.S. Economic growth and environmental degradation in Saudi Arabia. J. Econ. Sustain. Dev. 2015, 6, 33-44. Available online: https:/ /www.iiste.org/Journals/index.php/JEDS/article/view/19364/19941 (accessed on 14 December 2020).

7. Dimitrov, R.S. The Paris agreement on climate change: Behind closed doors. Glob. Environ. Politics 2016, 16, 1-11. [CrossRef]

8. Mitić, P.; Munitlak Ivanović, O.; Zdravković, A. A cointegration analysis of real GDP and $\mathrm{CO}_{2}$ emissions in transitional countries. Sustainability 2017, 9, 568. [CrossRef]

9. UNFCCC. The Paris Agreement. Available online: https://unfccc.int/process-and-meetings/the-paris-agreement/the-parisagreement (accessed on 11 December 2020).

10. Shafik, N. Economic development and environmental quality: An econometric analysis. Oxf. Econ. Pap. 1994, 46, 757-773. [CrossRef]

11. Panayotou, T. Environmental degradation at different stages of economic development. In Beyond Rio: The Environmental Crises and Sustainable Livelihoods in the Third World; Ahmed, I., Doeleman, J.A., Eds.; Macmillan Press: London, UK, 1995.

12. Grossman, G.M.; Krueger, A.B. Economic growth and the environment. Q. J. Econ. 1995, 110, 353-377. [CrossRef]

13. Ben Cheikh, N.; Ben Zaied, Y.; Chevallier, J. On the nonlinear relationship between energy use and $\mathrm{CO}_{2}$ emissions within an EKC Framework: Evidence from panel smooth transition regression in the MENA region. Res. Int. Bus. Financ. 2021, 55, 101331. [CrossRef]

14. Leal, P.H.; Marques, A.C. Rediscovering the EKC hypothesis for the 20 highest $\mathrm{CO}_{2}$ emitters among OECD countries by level of globalization. Int. Econ. 2020, 164, 36-47. [CrossRef]

15. Pata, U.K.; Aydin, M. Testing the EKC hypothesis for the top six hydropower energy-consuming countries: Evidence from fourier bootstrap ARDL procedure. J. Clean. Prod. 2020, 264, 121699. [CrossRef]

16. Swain, R.B.; Kambhampati, U.S.; Karimu, A. Regulation, governance and the role of the informal sector in influencing environmental quality? Ecol. Econ. 2020, 173, 106649. [CrossRef]

17. Kahia, M.; Ben Aïssa, M.S.; Charfeddine, L. Impact of renewable and non-renewable energy consumption on economic growth: New evidence from the MENA Net Oil Exporting Countries (NOECs). Energy 2016, 116, 102-115. [CrossRef]

18. Kahia, M.; Ben Aïssa, M.S.; Lanouar, C. Renewable and non-renewable energy use-economic growth nexus: The case of MENA Net Oil Importing Countries. Renew. Sustain. Energy Rev. 2017, 71, 127-140. [CrossRef]

19. Kahia, M.; Kadria, M.; Ben Aissa, M.S.; Lanouar, C. Modelling the treatment effect of renewable energy policies on economic growth: Evaluation from MENA countries. J. Clean. Prod. 2017, 149, 845-855. [CrossRef]

20. Kang, S.H.; Islam, F.; Tiwari, A.K. The dynamic relationships among $\mathrm{CO}_{2}$ emissions, renewable and non-renewable energy sources, and economic growth in India: Evidence from time-varying Bayesian VAR model. Struct. Chang. Econ. Dyn. 2019, 50, 90-101. [CrossRef] 
21. Omri, A.; Euchi, J.; Hasaballah, A.H.; Al-Tit, A.A. Determinants of environmental sustainability: Evidence from Saudi Arabia. Sci. Total. Environ. 2019, 657, 1592-1601. [CrossRef]

22. Amran, Y.A.; Alyousef, R.; Alabduljabbar, H. Renewable and sustainable energy production in Saudi Arabia according to Saudi Vision 2030; Current status and future prospects. J. Clean. Prod. 2020, 247, 119602. [CrossRef]

23. Allhibi, H.; Chowdhury, H.; Zaid, M.; Loganathan, B.; Alam, F. Prospect of wind energy utilization in Saudi Arabia: A review. Energy Procedia 2019, 160, 746-751. [CrossRef]

24. Al-Saleh, Y. Renewable energy scenarios for major oil-producing nations: The case of Saudi Arabia. Futures 2009, 41, 650-662. [CrossRef]

25. Gamal, R.E. Saudi Arabia Sees Domestic Energy Use Falling, Plans Re- Newables Push. $2019 . \quad$ Available online: https:/ / www.reuters.com/article/Us-Saudi-Energy-reforms/Saudi-Arabia-Sees-Domestic-Energy-Use-Falling-PlansRenewables-Push-idUSKCN1P918N (accessed on 14 December 2020).

26. Schattenmann, M. IAEA—International Atomic Energy Agency; Brill: Leiden, The Netherlands, 2010; pp. 353-354. [CrossRef]

27. Alshammari, Y.M.; Sarathy, S.M. Achieving $80 \%$ greenhouse gas reduction target in Saudi Arabia under low and medium oil prices. Energy Policy 2017, 101, 502-511. [CrossRef]

28. Alkhathlan, K.; Javid, M. Carbon emissions and oil consumption in Saudi Arabia. Renew. Sustain. Energy Rev. 2015, 48, 105-111. [CrossRef]

29. Grossman, G.; Krueger, A. Environmental impacts of a North American free trade agreement. Natl. Bur. Econ. Res. 1991. [CrossRef]

30. Bo, S. A literature survey on environmental Kuznets curve. Energy Procedia 2011, 5, 1322-1325. [CrossRef]

31. Saidi, K.; Omri, A. Reducing $\mathrm{CO}_{2}$ emissions in OECD countries: Do renewable and nuclear energy matter? Prog. Nucl. Energy 2020, 126, 103425. [CrossRef]

32. Ben Youssef, A.; Hammoudeh, S.; Omri, A. Simultaneity modeling analysis of the environmental Kuznets curve hypothesis. Energy Econ. 2016, 60, 266-274. [CrossRef]

33. Sugiawan, Y.; Managi, S. The environmental Kuznets curve in Indonesia: Exploring the potential of renewable energy. Energy Policy 2016, 98, 187-198. [CrossRef]

34. Congregado, E.; Feria-Gallardo, J.; Golpe, A.A.; Iglesias, J. The environmental Kuznets curve and $\mathrm{CO}_{2}$ emissions in the USA. Environ. Sci. Pollut. Res. 2016, 23, 18407-18420. [CrossRef]

35. Balaguer, J.; Cantavella, M. Estimating the environmental Kuznets curve for Spain by considering fuel oil prices (1874-2011). Ecol. Indic. 2016, 60, 853-859. [CrossRef]

36. Yao, S.; Zhang, S.; Zhang, X. Renewable energy, carbon emission and economic growth: A revised environmental Kuznets curve perspective. J. Clean. Prod. 2019, 235, 1338-1352. [CrossRef]

37. Kacprzyk, A.; Kuchta, Z. Shining a new light on the environmental Kuznets curve for $\mathrm{CO}_{2}$ emissions. Energy Econ. 2020, 87, 104704. [CrossRef]

38. Chen, Q.; Taylor, D. Economic development and pollution emissions in Singapore: Evidence in support of the environmental Kuznets curve hypothesis and its implications for regional sustainability. J. Clean. Prod. 2020, 243, 118637. [CrossRef]

39. Charfeddine, L.; Kahia, M. Impact of renewable energy consumption and financial development on $\mathrm{CO}_{2}$ emissions and economic growth in the MENA region: A panel vector autoregressive (PVAR) analysis. Renew. Energy 2019, 139, 198-213. [CrossRef]

40. Silva, S.; Soares, I.; Pinho, C. The impact of renewable energy sources on economic growth and $\mathrm{CO}_{2}$ emissions-A SVAR approach. Eur. Res. Stud. J. 2012, 133-144. [CrossRef]

41. Love, I.; Zicchino, L. Financial development and dynamic investment behavior: Evidence from panel VAR. Q. Rev. Econ. Financ. 2006, 46, 190-210. [CrossRef]

42. Kahia, M.; Ben Jebli, M.; Belloumi, M. Analysis of the impact of renewable energy consumption and economic growth on carbon dioxide emissions in 12 MENA countries. Clean Technol. Environ. Policy 2019, 21, 871-885. [CrossRef]

43. Mendonça, A.D.S.; Barni, G.D.A.C.; Moro, M.F.; Bornia, A.C.; Kupek, E.; Fernandes, L. Hierarchical modeling of the 50 largest economies to verify the impact of GDP, population and renewable energy generation in $\mathrm{CO}_{2}$ emissions. Sustain. Prod. Consum. 2020, 22, 58-67. [CrossRef]

44. Saidi, K.; Omri, A. The impact of renewable energy on carbon emissions and economic growth in 15 major renewable energyconsuming countries. Environ. Res. 2020, 186, 109567. [CrossRef]

45. Cherni, A.; Essaber Jouini, S. An ARDL approach to the $\mathrm{CO}_{2}$ emissions, renewable energy and economic growth nexus: Tunisian evidence. Int. J. Hydrog. Energy 2017, 42, 29056-29066. [CrossRef]

46. Dong, K.; Sun, R.; Jiang, H.; Zeng, X. $\mathrm{CO}_{2}$ emissions, economic growth, and the environmental Kuznets curve in China: What roles can nuclear energy and renewable energy play? J. Clean. Prod. 2018, 196, 51-63. [CrossRef]

47. Emir, F.; Bekun, F.V. Energy intensity, carbon emissions, renewable energy, and economic growth nexus: New insights from Romania. Energy Environ. 2019, 30, 427-443. [CrossRef]

48. Ozturk, I.; Acaravci, A. $\mathrm{CO}_{2}$ emissions, energy consumption and economic growth in Turkey. Renew. Sustain. Energy Rev. 2010, 14, 3220-3225. [CrossRef]

49. Kivyiro, P.; Arminen, H. Carbon dioxide emissions, energy consumption, economic growth, and foreign direct investment: Causality analysis for Sub-Saharan Africa. Energy 2014, 74, 595-606. [CrossRef] 
50. Omri, A.; Daly, S.; Rault, C.; Chaibi, A. Financial development, environmental quality, trade and economic growth: What causes what in MENA countries. Energy Econ. 2015, 48, 242-252. [CrossRef]

51. Bouznit, M.; Pablo-Romero, M. $\mathrm{CO}_{2}$ Emission and Economic Growth in Algeria. Energy Policy 2016, 96, 93-104. [CrossRef]

52. Zoundi, Z. $\mathrm{CO}_{2}$ emissions, renewable energy and the environmental Kuznets curve, a panel cointegration approach. Renew. Sustain. Energy Rev. 2017, 72, 1067-1075. [CrossRef]

53. Sadorsky, P. Renewable energy consumption and income in emerging economies. Energy Policy 2009, 37, 4021-4028. [CrossRef]

54. Apergis, N.; Payne, J.E. Renewable energy consumption and economic growth: Evidence from a panel of OECD countries. Energy Policy 2010, 38, 656-660. [CrossRef]

55. Leitao, N.C. Economic growth, carbon dioxide emissions, renewable energy and globalization. Int. J. Energy Econ. Policy 2014, 4 , 391-399.

56. Koçak, E.; Şarkgüneşi, A. The renewable energy and economic growth nexus in Black Sea and Balkan countries. Energy Policy 2017, 100, 51-57. [CrossRef]

57. Venkatraja, B. Does renewable energy affect economic growth? Evidence from panel data estimation of BRIC countries. Int. J. Sustain. Dev. World Ecol. 2019, 27, 107-113. [CrossRef]

58. Apergis, N.; Payne, J.E.; Menyah, K.; Wolde-Rufael, Y. On the causal dynamics between emissions, nuclear energy, renewable energy, and economic growth. Ecol. Econ. 2010, 69, 2255-2260. [CrossRef]

59. Menyah, K.; Wolde-Rufael, Y. $\mathrm{CO}_{2}$ emissions, nuclear energy, renewable energy and economic growth in the US. Energy Policy 2010, 38, 2911-2915. [CrossRef]

60. Bélaïd, F.; Youssef, M. Environmental degradation, renewable and non-renewable electricity consumption, and economic growth: Assessing the evidence from Algeria. Energy Policy 2017, 102, 277-287. [CrossRef]

61. Bhattacharya, M.; Churchill, S.A.; Paramati, S.R. The dynamic impact of renewable energy and institutions on economic output and $\mathrm{CO}_{2}$ emissions across regions. Renew. Energy 2017, 111, 157-167. [CrossRef]

62. Waheed, R.; Chang, D.; Sarwar, S.; Chen, W. Forest, agriculture, renewable energy, and $\mathrm{CO}_{2}$ emission. J. Clean. Prod. 2018, 172, 4231-4238. [CrossRef]

63. Dong, K.; Hochman, G.; Zhang, Y.; Sun, R.; Li, H.; Liao, H. $\mathrm{CO}_{2}$ emissions, economic and population growth, and renewable energy: Empirical evidence across regions. Energy Econ. 2018, 75, 180-192. [CrossRef]

64. Akbostanc1, E.; Türüt-Aşık, S.; Tunç, G.I. The relationship between income and environment in Turkey: Is there an environmental Kuznets curve? Energy Policy 2009, 37, 861-867. [CrossRef]

65. Kalayci, C.; Hayaloglu, P. The impact of economic globalization on $\mathrm{CO}_{2}$ emissions: The case of NAFTA countries. Int. J. Energy Econ. Policy 2019, 9, 356-360.

66. Salahuddin, M.; Gow, J.; Ali, I.; Hossain, R.; Al-Azami, K.S.; Akbar, D.; Gedikli, A. Urbanization-globalization-CO 2 emissions nexus revisited: Empirical evidence from South Africa. Heliyon 2019, 5, e01974. [CrossRef] [PubMed]

67. Abdmouleh, Z.; Alammari, R.A.M.; Gastli, A. Recommendations on renewable energy policies for the GCC countries. Renew. Sustain. Energy Rev. 2015, 50, 1181-1191. [CrossRef]

68. Mezher, T.; Dawelbait, G.; Abbas, Z. Renewable energy policy options for Abu Dhabi: Drivers and barriers. Energy Policy 2012, 42, 315-328. [CrossRef] 